\title{
Satellite Telemetry of Blue-Throated Macaws in Barba Azul Nature Reserve (Beni, Bolivia) Reveals Likely Breeding Areas
}

\author{
Lisa C. Davenport ${ }^{1,2, *}$, Tjalle Boorsma ${ }^{3}$, Lucas Carrara ${ }^{4}$, Paulo de Tarso Zuquim Antas ${ }^{5}\left(\mathbb{D}\right.$, Luciene Faria ${ }^{4}$, \\ Donald J. Brightsmith ${ }^{6}$, Sebastian K. Herzog ${ }^{3,7}$, Rodrigo W. Soria-Auza ${ }^{3,7, *}$ and A. Bennett Hennessey ${ }^{3}$ \\ 1 Florida Natural History Museum, Department of Biology, University of Florida Gainesville, \\ Gainesville, FL 32611, USA \\ 2 College of Marine and Environmental Sciences, James Cook University, Cairns, QLD 4878, Australia \\ 3 Asociación Civil Armonía, Zona Palmasola, Santa Cruz, Bolivia; tboorsma@armonia-bo.org (T.B.); \\ skherzog@armonia-bo.org (S.K.H.); abhennessey@armonia-bo.org (A.B.H.) \\ 4 Aves Gerais, Belo Horizonte 30431-236, MG, Brazil; lucas.avesgerais@gmail.com (L.C.); \\ luciene.avesgerais@gmail.com (L.F.) \\ 5 Fundação Pró-Natureza (Funatura), Brasilia 70743-520, DF, Brazil; ptzantas@gmail.com \\ 6 Schubot Avian Health Center, Department of Veterinary Pathobiology, Texas A \& M University, \\ College Station, TX 77843, USA; Brightsmith1@tamu.edu \\ 7 Museo de Historia Natural Alcide d'Orbigny, Cochabamba, Bolivia \\ * Correspondence: ldavenport@parkswatch.org (L.C.D.); wilbersa@armonia-bo.org (R.W.S.-A.)
}

check for updates

Citation: Davenport, L.C.; Boorsma, T.; Carrara, L.; Antas, P.d.T.Z.; Faria, L.; Brightsmith, D.J.; Herzog, S.K.; Soria-Auza, R.W.; Hennessey, A.B. Satellite Telemetry of Blue-Throated Macaws in Barba Azul Nature Reserve (Beni, Bolivia) Reveals Likely Breeding Areas. Diversity 2021, 13, 564. https://doi.org/10.3390/ d13110564

Academic Editors: José L. Tella Guillermo Blanco and Martina Carrete

Received: 21 September 2021

Accepted: 29 October 2021

Published: 5 November 2021

Publisher's Note: MDPI stays neutral with regard to jurisdictional claims in published maps and institutional affiliations.

Copyright: (c) 2021 by the authors. Licensee MDPI, Basel, Switzerland. This article is an open access article distributed under the terms and conditions of the Creative Commons Attribution (CC BY) license (https:// creativecommons.org/licenses/by/ $4.0 /)$.
Abstract: The Blue-throated Macaw (Ara glaucogularis) is a Critically Endangered species endemic to the Llanos de Moxos ecosystem of Beni, Bolivia. To aid conservation of the northwestern population that utilizes the Barba Azul Nature Reserve during the non-breeding season, we set out to learn the sites where these birds breed using satellite telemetry. We describe preliminary tests conducted on captive birds (at Loro Parque Foundation, Tenerife, Spain) that resulted in choosing Geotrak Parrot Collars, a metal, battery-operated unit that provides data through the Argos satellite system. In September 2019, we tagged three birds in Barba Azul with Geotrak collars, and received migration data for two birds, until battery depletion in November and December 2019. Our two migrant birds were tracked leaving Barba Azul on the same date (27 September), but departed in divergent directions (approximately 90 degrees in separation). They settled in two sites approximately $50-100 \mathrm{~km}$ from Barba Azul. Some details of the work are restricted out of conservation concern as the species still faces poaching pressures. Knowing their likely breeding grounds, reserve managers conducted site visits to where the birds were tracked, resulting in the discovery of breeding birds, although no birds still carrying a transmitter were seen then. A single individual still carrying its collar was spotted 13 August 2021 at Barba Azul. The work suggests that the Blue-throated Macaws of Barba Azul use breeding sites that are scattered across the Llanos de Moxos region, although within the recognized boundaries of the northwestern subpopulation. We conclude that the use of satellite collars is a feasible option for research with the species and could provide further conservation insights.

Keywords: Psittacidae; Ara glaucogularis; migration; daily behavioral patterns; Llanos de Moxos

\section{Introduction}

The technology used to track animal movements with miniaturized, animal-borne devices is advancing rapidly and opening up many new avenues of animal research [1-5]. In avian studies, tracking technology is typically used to tag birds caught on their breeding grounds, and to track them remotely to learn about annual movements, migrations routes, reproductive parameters, foraging behaviors, and stopover ecology. Examples hail from around the world and for a wide range of taxa including Magellanic Penguins [6], raptors in the Americas [7,8], Black Skimmers migrating over the Andes [9], waterfowl in Africa [10], upland sandpipers in Western Hemisphere [11], and nomadic Banded Stilts of Australia [12]. These and other studies provide valuable information for better understanding birds' lives 
and conservation needs, as well as providing scientific insight into important questions about birds' sensory abilities, and their behavior in changing environments [3].

Far less common than tracking animals from their breeding grounds is tracking them to their breeding locations. Some examples exist tracking marine vertebrates (e.g., Atlantic tuna [13] and green turtles [14]). For birds, Takekawa et al. [15] tracked East Asian waterbirds to breeding grounds to study potential routes of transmission of avian influenza outbreaks, and shorebirds have been tracked from flyway locations ([16]. Many parrots have relatively well-known breeding areas, although for some macaw species, including Lear's Macaw (Anodorhynchus leari) and Great Green Macaws (Ara ambiguus), breeding areas were unknown until late in the 20th century [17-19]. For long-lived birds such as parrots, one of the most critical determinants of a species' demography is breeding success; however, conservationists often need information on rare parrots' reproductive seasons, behaviors, and success. Such is the case for the northern population of the Critically Endangered Blue-throated Macaw (Ara glaucogularis-henceforth "BTM") in Beni, Bolivia, for which knowledge of breeding ground locations, and some basic reproductive strategies and parameters are largely unknown. Such information can be aided by telemetry studies, yet these are difficult to implement for most parrot species.

Harvest for the pet trade in the 1960s and 1970s helped to push the BTM to the brink of extinction [20,21], and the location of its remnant wild population was unknown until its re-discovery in 1992 [20]. The species is endemic to the Llanos de Moxos ecosystem of the Beni, a 12,000,000-ha expanse of treeless grasslands, wetlands, cerrado-like savanna, palm savanna, and palm forest islands that is flooded approximately 6 months per year from October to May [22-25]. BTMs require forest islands that harbor one of its preferred feeding and roosting trees, the Motacú palm (Attalea princeps) [22]. In the breeding season, it requires large tree cavities for nesting, demonstrating high nest site fidelity to both artificial and natural cavities [26]. Between 312 and 455 BTMs are thought to remain in the wild [22]. These are divided among three potentially isolated subpopulations in the northwestern, northeastern, and southern Beni [22]. In 2008, a private 11,000-ha reserve, the Barba Azul Nature Reserve (henceforth "Barba Azul") was established in the northwestern part of the range to protect the groups that use the area during the nonbreeding season (estimated at approximately 160-200 individuals by [27]).

While satellite telemetry is a potentially useful technology for enhancing conservation goals in Barba Azul, the task of tracking wild parrots across large areas and over many months is a formidable challenge. Few Platform Transmitter Terminal (PTT) units available today are able to resist the great intelligence, strong beaks, and flexible necks and tongues of most large parrots, and many species can easily remove attached transmitters in minutes [28]. However, species and individuals vary, and field researchers have therefore had some successes with a few larger species that have carried telemetry units for months and allowed useful data on landscape-level movements [28-31]. Since no previous telemetry studies exist on the BTM, and it is smaller than macaws previously studied, we felt it vital to test potential tag models in a controlled environment prior to working with wild birds. Moreover, to ensure the Barba Azul Reserve's continued viability as a center of conservation and ecotourism, we needed to trap and study wild birds while causing the least possible disruption to the known roosting, feeding, and tourist-viewing sites.

The overriding goals of this study were to: (1) test available technologies on captive birds to determine the safest and most appropriate techniques, and (2) to safely tag and track wild BTMs living at Barba Azul to determine the location of their breeding sites and understand more about local movement patterns, distances traveled, and resources used.

\section{Materials and Methods}

\subsection{Data Accessibility}

Because of ongoing poaching of BTMs, especially on their nests and outside of protected areas, we chose not to share all the tracking data obtained in the study. We do provide access to tracking data within and near to the limits of the Barba Azul Nature 
Reserve, where the birds are protected from poaching [32]. We also redacted some of the specifics of our capture methods of wild birds. Researchers with valid requests for additional specifics about methods and tracking data can write to the corresponding author and/or Asociación Armonía (Rodrigo W. Soria-Auza, email: wilbersa@armonia-bo.org) for further details.

\subsection{Study Site: Barba Azul Nature Reserve}

The study was conducted in the seasonally inundated savannahs and forest islands of the Llanos de Moxos in the northern part of the Beni Department of Bolivia. Mean annual precipitation in the region is approximately $1800 \mathrm{~mm}$ with most rain falling between October and May [33]. Nearly the entirety of the Llanos de Moxos habitat in northern Beni $(\sim 12,000,000 \mathrm{ha})$ is subject to cattle ranching and associated land management practices, including areas within declared protected areas. Within the entire Llanos de Moxos, there is one national protected area (Estación Biológica del Beni, of 135,200 ha), municipal reserves $(1,222,400$ ha total), and private protected areas (106,000 ha total). These municipal reserves were declared on top of private land claims and some are overlapping. Also superimposed on these areas are 6,920,200 ha of RAMSAR sites that confer international recognition to the areas as important waterbird habitats, but do not currently translate into any regulation on the ground [34].

Barba Azul Nature Reserve is an agglomeration of multiple private parcels now under a single management unit. The 11,000-ha reserve was created by Asociación Armonía in 2008 with support from American Bird Conservancy, the International Conservation Fund of Canada, IUCN Netherlands, Rainforest Trust, US Fish and Wildlife Service, and the World Land Trust. The study site is located on the Rio Omi in the extremely flat floodplain between the Mamoré and the Beni Rivers, which flow North through Bolivia to the main trunk of the Amazon (Figure 1). The reserve protects wetlands along the Rio Omi, small forest islands of anthropic origin, naturally fragmented gallery forests, and cerrado-like savanna.

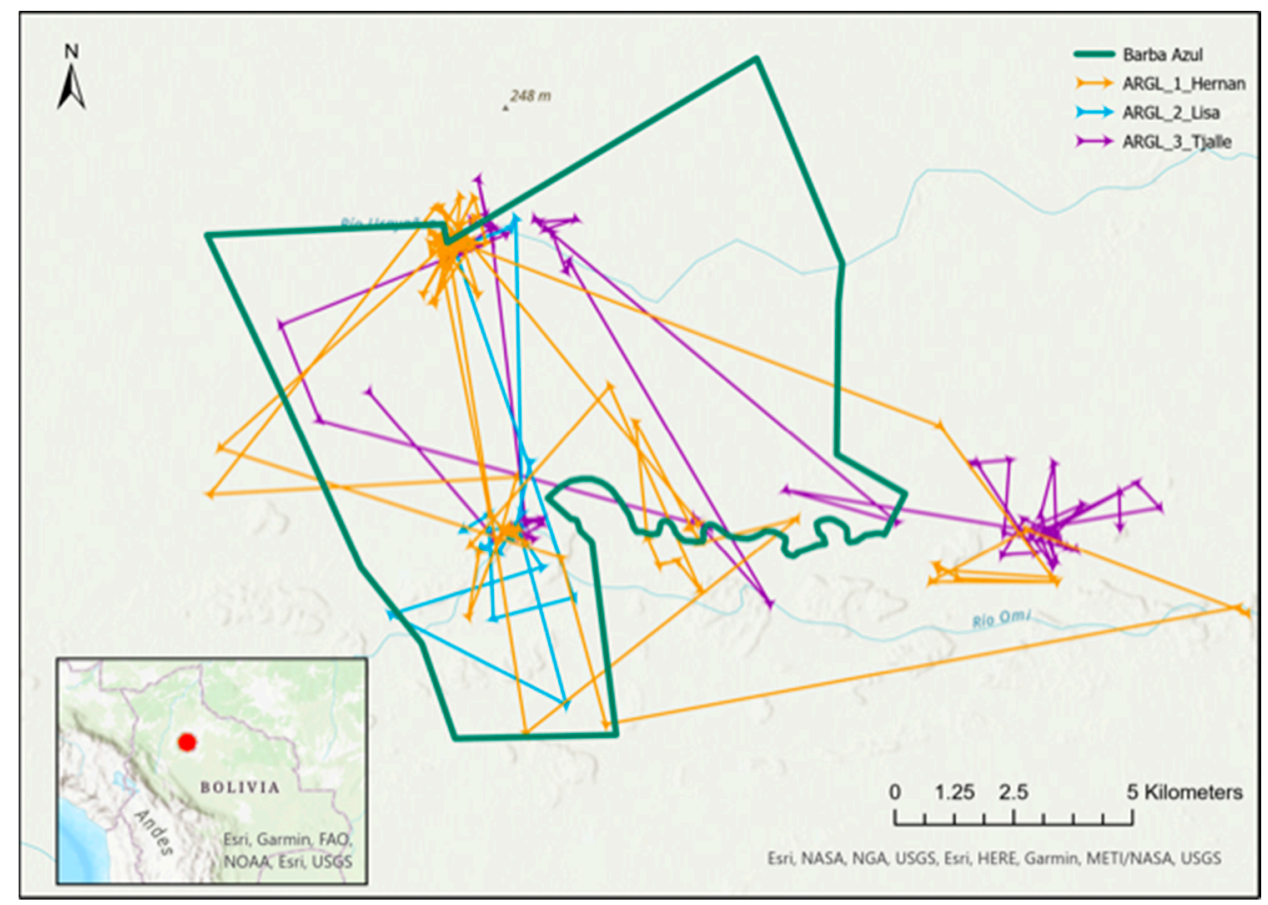

Figure 1. Map of Barba Azul Nature Reserve (inside green boundary) on the Rio Omi, with tracks of 3 Blue-throated macaws in and adjacent to reserve. Argos LC Classes A-3 with DAF filtering. Nicknames of birds used within Movebank and "Animal Tracker" app are appended to codes. Created in ARCGIS Pro 2.7. 
There are 6000 ha dedicated to strict conservation use and the other 5000 ha are managed for low-impact cattle ranching, because Bolivia's Función Economico Social (FES) policy ties land titles to a requirement for remunerative agricultural production. A description of the Llanos de Moxos wetland/savanna habitat mosaic, specific characteristics of the reserve's habitats and its history of anthropogenic use, as well as the detrimental local effects of cattle ranching on the Blue-Throated Macaws' main feeding tree, Atalaea principeps, have been described elsewhere [22,23,35-37].

Groups of up to 155 BTMs have been counted at Barba Azul and annual counts have showed slow increases in their numbers [22,27]. The birds are almost exclusively present in the non-breeding season, in contrast to the southern population, where they appear to be resident year-round. The departure of BTMs from Barba Azul just before the breeding season suggests a regular migratory movement between this dry season congregation site and unknown breeding grounds. The impulse to migrate from Barba Azul, we suspect, is due to the local rarity of Mauritia palms, a known nesting tree, so long as adequate feeding resources are also available in the vicinity [27].

The flocks are present in predictable numbers and locations around the reserve every dry season, and we suspect that these are the same birds that return each year [27]. The BTM is known to use nest boxes in the southern population [22], but nest boxes in Barba Azul have attracted only one pair of Blue-throated Macaws in 2019 and have yet to result in successful reproduction [27].

Wet season surveys conducted by Asociación Armonía to find breeding BTMs in the northwestern population in 2017 and 2020 have located 15 active nests so far [27]. Whether these are the same sites used by the birds using the Barba Azul is still uncertain. The remoteness of the region, the difficulty of access during wet-season flooding, and private ownership concerns are all factors that have hindered locating the breeding grounds of Barba Azul birds.

\subsection{Attachment Tests}

After approaching multiple institutions unsuccessfully, we were finally allowed to conduct fit and durability tests of satellite transmitters on 5 captive BTMs at the Loro Parque Foundation (Tenerife, Spain). All birds were males housed together in a group. We tested 3 models of dummy collars (made by Ecotone (Gdynia, Poland): $\mathrm{n}=1$ unit; Telenax (Queretaro, Mexico): $\mathrm{n}=3$ units and Geotrak (Raleigh, NC USA): $\mathrm{n}=1$ unit) and 2 types of dummy backpacks (Ecotone $\mathrm{n}=1$ and Microwave Telemetry, Inc. (Columbia, MD USA): $n=1$ ). Outer shells of the Ecotone and Microwave Telemetry, Inc. units are made of hardened plastic, as were collars used on these units. Telenax and Geotrak collars were made of metal, with rubber coverings. MTI, Geotrak, and 2 Telenax units had external antennae, while the Ecotone units and 1 Telenax unit did not. Backpack harnesses were custom fit with $1 / 3^{\prime \prime}$ width Teflon ribbon using a customizable protocol used with Orinoco geese [38]. One Ecotone backpack unit was painted blue to see if camouflage would reduce the wearer's attacks on the unit. Super glue was added as reinforcement on all knots and attachment points. All harnessing was conducted by Loro Parque Foundation caretakers and LCD. We video-taped the birds' reactions to wearing some of the units (Supplemental Video S1) and allowed Loro Parque Foundation care-takers to determine timing for all removals.

\subsection{Capture of Wild BTMs}

We assessed the options for trapping over three different dry seasons (2017-2019). Given the importance of this area for large numbers of this Critically Endangered species, our goal was to minimize disruption of important roosting, feeding, and tourism sites. As a result, we aimed to capture a small number of birds at a time in isolated locations. The methods used were approved under University of Florida Gainesville IACUC study permit \#201709973. Permits for working in Barba Azul were obtained through the Museum of Natural History Alcide d'Orbigny. The specific method used for final captures is not 
reported here, out of conservation concern. Ultimately, we trapped four birds at a forest patch used by small groups of birds, over about 1 week, just before the start of the breeding season in August-September 2019. Although all birds were trapped at the same site, the movement data did not suggest that any of the collared birds were traveling in pairs or as parents and offspring.

\subsection{Tagging}

After tests on captive birds proved the suitability of Geotrak Argos units (see Results), we attached active Geotrak satellite parrot PTT collars to 3 of the 4 birds captured between 31 August and 9 September 2019 (see Supplementary Materials Table S1). Each bird was calmed by putting a breathable cotton hood over the head with a drawstring opening that allowed it to breathe unimpeded; legs and beak were immobilized using black electrical tape. All birds were measured and weighed prior to attaching a tag (Supplemental Table S1). All 3 tagged birds' body mass exceeded the minimum required for the transmitter weight to meet the standard limit in avian telemetry studies of $<5 \%$ body weight [39]. Collars were produced with adjustable neck bands, so were fitted to each bird, with a small bolt permanently inserted and glued at the appropriate neckband hole. We noted start and end times of all procedures, periodically assessed the bird's condition, took photos and video of the procedure, photographed the feather and face patterns, and recorded their behavior and flight ability upon release (Supplemental Video S2). All movement data from within Barba Azul and auxiliary data are archived in the Movebank Data Repository [32].

\subsection{Programming and Location Accuracy}

The Geotrak parrot collar is a battery-operated unit, with no option to have a solar panel or external charger to recharge the internal battery. We therefore had to choose whether to prioritize an extended period of use or higher quality data, with more frequent location fixes. Not knowing how long the units would survive on the birds (especially fearing they might quickly succeed at detaching them), we chose to prioritize collecting higher quality data. The units were therefore programmed by the manufacturer so that about 3 months of data would be collected. A duty cycle of up to $5 \mathrm{~h}$ on, followed by 2 days off was programmed, dependent on satellite availability. We assumed from previous observations at Barba Azul that migration to the breeding grounds would occur in October, so that the units should have given us approximately half their data from Barba Azul and half from the breeding grounds. The units provide Doppler based locations calculated by the Argos system, which vary between $500 \mathrm{~m}$ and $5 \mathrm{~km}$ accuracy depending on Location Class (LC), with LC B being the lowest accuracy and LC 3 the highest accuracy $[40,41]$.

\subsection{Analyses}

All data received from the ARGOS satellite system were filtered with the Kalman filter and uploaded in a live feed to Movebank.org for analysis and archival purposes. We inspected data to determine when tags were likely no longer on a moving animal; these were determined due to (a) failure to travel to night roosts, and (b) abrupt loss of reporting regularity and signal quality (low LC classes only). We performed three types of analyses on the data: (1) For all birds, we calculated "Home Range" estimates for the full dataset, (2) we calculated home range estimates for subsets of data from the dry season and wet season, and (3) we plotted time from capture against accumulated distance traveled by the 2 birds that migrated out of Barba Azul. Distances traveled within dry vs. wet season areas and on migration were calculated by choosing one "Best of Day" point that was the highest LC point provided on that day (either an LC 3 or 2), and applying the Haversine Great Circle distance between daily points. We report on maximum distances between daily points at dry vs. wet sites, and accumulated distances traveled throughout the study for the two birds that undertook an outbound migration.

Home Range Estimation: For the purposes of home range analysis, we retained Argos Location classes 3 through A, and then applied a Douglas Filter (available through 
Movebank.org filter options) that removed locations with unrealistic distance and turning angles between 3 points, with a minimum turning angle of 35 degrees and $50 \mathrm{~km} / \mathrm{h}$ maximum flight speed [42]. For each bird, we calculated 95\% Autocorrelated Kernel Density Estimates (AKDE) to represent overall area (in hectares) used by each bird, both for the full dataset, and the subsets during wet season (breeding period) and dry season while at Barba Azul. From the Barba Azul and wet season data, we also present a "core home range" represented by the $70 \%$ AKDE at both dry and wet season locations. All AKDE analyses were performed using the R program "ctmm" [43-45]. Within the "ctmm" program, we used the "ctmm.select" procedure to choose the utilization distribution that best fit the data based on AIC comparisons. For both ARGL1 and ARGL3, the selection procedure based on data in and around Barba Azul and for the complete dataset resulted in selecting a model with correlated positions but uncorrelated velocities, or "OU" (for Ornstein-Uhlenbeck) anisotropic utilization distributions [46,47]. For the wet season data, the selection procedure resulted in selecting an "OU" anisotropic model for ARGL3, but an "IID" anisotropic utilization distribution that assumes no correlated locations or velocities [47]. In the Llanos de Moxos habitats, all these range estimates include large areas of what we consider "flyover" space (open savannas, which are not used by macaws), between heavily-used forest patches. While these calculations may be crude estimates of space of importance to the birds, from the perspective of reserve design and management, the analysis is helpful to calculate a rough areal extent required for conservation of the species in situ. The choice of these methods also allows comparisons with similar datasets on other wild macaw species that used comparable methods.

\subsection{Wet Season Nest Surveys}

After tracking BTMs that left Barba Azul, nest site searches were undertaken around the Department of Beni by Asociación Armonía staff in the following wet season to assess if BTMs remained in the areas indicated by GPS locations. In February and March of 2020 (after all transmissions had stopped), T.B. and other Asociación Armonía staff undertook horseback surveys through large areas of the northern Beni to look for nesting sites there and further afield [27,48]. At the same time, landowners in the region were contacted to discuss the ongoing tracking program and conservation efforts of Armonía.

\section{Results}

\subsection{PTT Dummy Testing}

Observations (and photos plus video recordings) documented how captive BTMs at Loro Parque Foundation treated different models of transmitters and attachment methods, and, most importantly, how they managed to render the units inoperable. Both the Ecotone unit placed as a collar and the one placed as a backpack were destroyed in minutes by piercing the casing and breaking off large chunks of the plastic housing (Figure 2b). The MTI backpack model fared somewhat better, but Teflon was quickly removed at the attachment points so that the unit then sat high near the neck rather than centered on the back, and then the antennae and casing were both opened (Supplemental Video S1). With the metal collars made by Telenax and Geotrak, the material and rounded shape of the units did inhibit their immediate destruction, especially of the casings. However, only one of the four metal collars, the Geotrak unit, was allowed to remain on a Loro Parque BTM for more than eight days by Loro Parque caretakers. Antennae on two Telenax were quickly chewed, exposing wires, so those units were removed immediately. The remaining Telenax collar was found after eight days to have been causing cuts on the bird's neck after the wearer chewed off all the protective rubber on the neckband, exposing the end of a metal seam behind the nut (Figure 3d). Somewhat surprisingly, the long straight antenna that extends beyond the Geotrak unit, up behind the head, was not a focus of attention, thus it remained intact. According to M. Weinzetll, curator at Loro Parque, the birds focused attention, especially early on, on breaking the metal collar on the Geotrak unit, but they did not succeed during the test period. Some, but not all, of the protected rubber shielding was 
removed at the sides. The outer case was deformed, but never pierced (Figure 3e,f). The single Geotrak collar unit tested remained on its captive BTM for 27 days, at which point it was also removed by caretakers. At the time of removal, caretakers reported the bird was tolerating the unit well, and the unit did not seem to limit flying, feeding, or self-grooming. They further determined that the unit caused two small feather cysts, but no significant injury [49]. A comparison of the case of an untested unit (upper) and the tested unit (lower) are shown in Figure 3f. We deemed the Geotrak model to be the only suitable unit for use on wild birds.

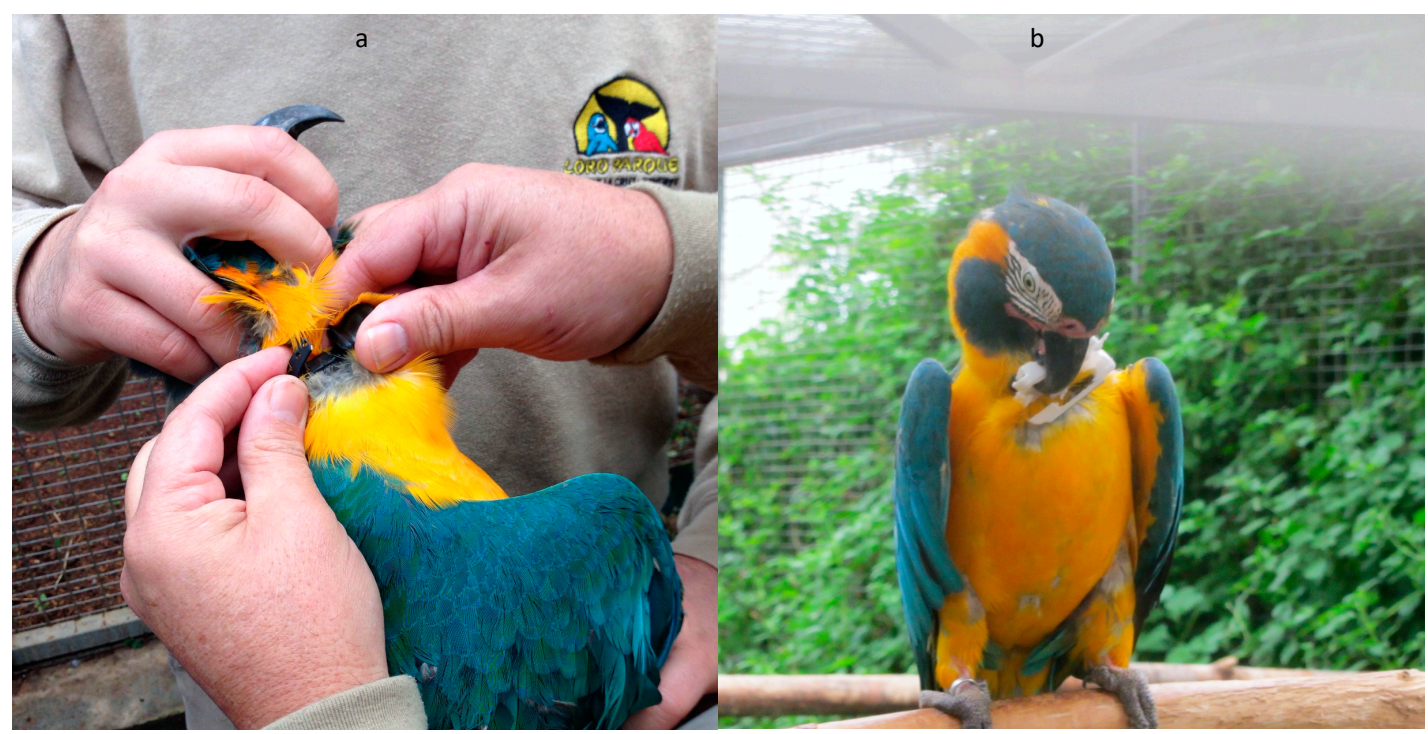

Figure 2. Testing dummy units at Loro Parque (Tenerife, Spain): (a) attachment of a Telenex collar; (b) captive BTM opening the Ecotone unit set as a collar. See also Supplemental Video S1 for video of a testing episode with the MTI backpack unit.

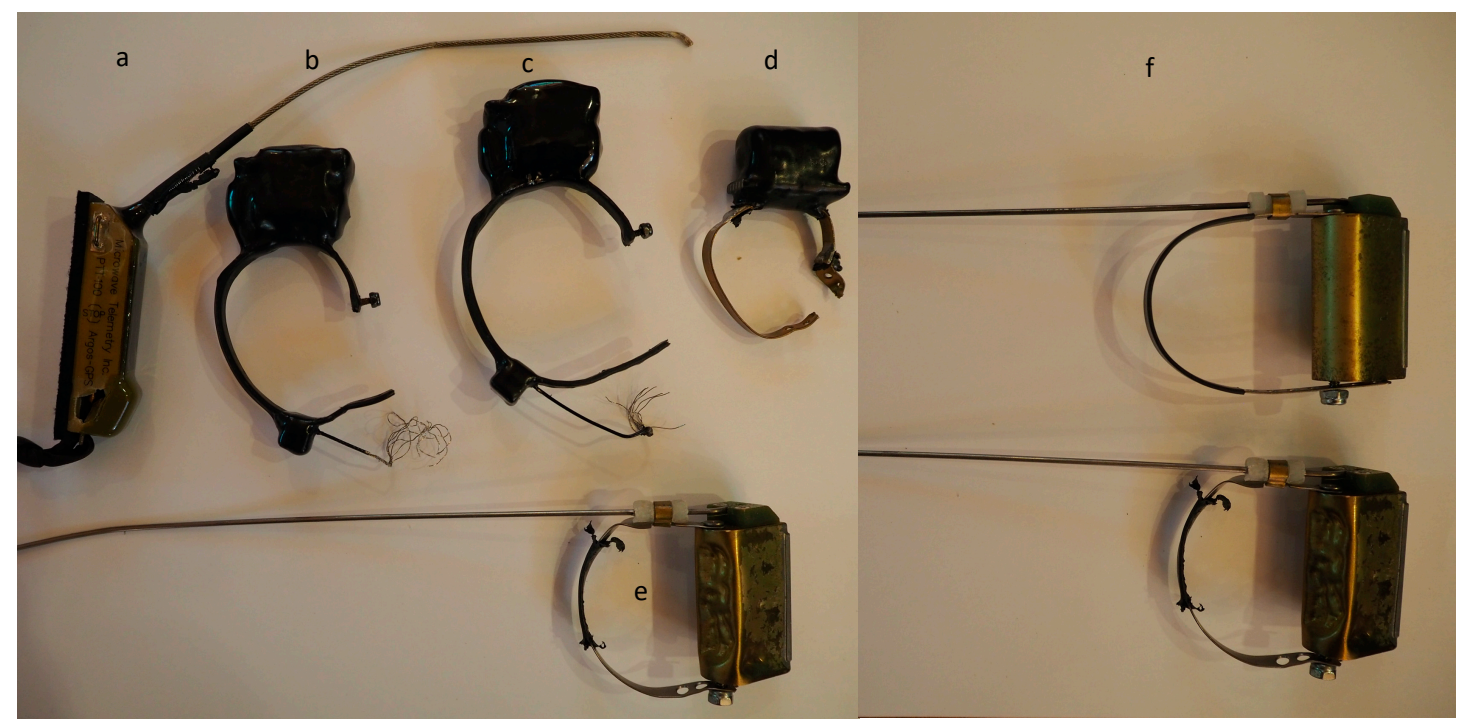

Figure 3. Units retrieved from tests on captive Loro Parque BTMs: (a) MTI set as backpack; (b-d) Telenax collars; (e) Geotrak parrot collar; (f) comparison of an untested Geotrak collar (upper) and the collar tested for 27 days on a captive BTM (lower).

\subsection{Satellite PTT Performance}

We received a total of 655 Argos locations (LC Class B or better, excluding duplicate timestamps) over the course of the study. On average, duty cycles returned locations for $3.1( \pm 1.6 \mathrm{SD})$ hours, then cycled off for $2.2( \pm 0.6)$ days. Data quality was high, with $54 \%$ of the points in the 2 highest Argos Locations Classes (LC 2 and 3). After truncating and 
filtering data as described above, we obtained 266 locations spanning 117.1 days from ARGL1 (31 August 2019 to 26 December 2019) and 218 locations over 79.5 days from ARGL3 (9 September to 28 November 2019). Subsets of the data used in home range analyses included: (1) 63 points for ARGL1, and 23 points for ARGL3 within the vicinity of Barba Azul; and, (2) 115 points for ARGL1, and 131 points for ARGL3 on purported breeding (wet season) grounds. We only received 24 usable locations over 6.6 days from ARGL2 (1 September-8 September 2019). This collar continued transmitting from a stationary point within the reserve from 10 September until 20 November. Though the area was extensively searched on foot several times (by T.B.), neither the collar, feathers, nor a carcass were found, suggesting that the collar was removed by the bird or its family members. Results from ARGL2 were of such limited duration that they are only considered with respect to the bird's movements relative to the other tracked birds in the earliest days of the study.

\subsection{Range Size, Movements, and Observations around Barba Azul}

The tracking data collected while the three BTMs were in and near to Barba Azul showed them moving independently while using similar areas of Barba Azul known to be popular with flocks, including the three largest forest islands and two known nighttime roosts (Figure 1). An animation of the data based on interpolated timestamps demonstrated that, while the three tagged macaws used similar areas and often roosted together at night, they mostly foraged separately, suggesting that they belong in distinct family groups (Supplemental Video S3). In addition, birds used one previously unknown daytime feeding area outside the reserve near the Rio Omi and one previously unknown nighttime roost. While in the Barba Azul area, ARGL1 moved on average $4.7 \mathrm{~km}$ between consecutive days; ARGL2 $3.4 \mathrm{~km}$, and ARGL3 $2.7 \mathrm{~km}$. For the two birds with adequate data to calculate AKDE home range size, the overall area of use was similar at 22,593 ha for ARGL1 (see Table 1 for $95 \%$ confidence limits)) vs. 27,066 ha for ARGL3, while core area of use (70\% AKDE) was 8415 ha for ARGL1 and 12,551 ha for ARGL3. (Also see Supplemental Figure S1 for a diagram of $95 \%$ Home Range limits in the Barba Azul region).

Table 1. Home Range Estimates (with 95\% CI in parentheses) of BTMs in total area of use, dry season (Barba Azul), and wet season locations by AKDE methods in "ctmm" program.

\begin{tabular}{cccccc}
\hline & Total 95\% AKDE (ha) & Wet 95\% AKDE (ha) & $\begin{array}{c}\text { Dry (Barba Azul) } \\
\text { 95\% AKDE (ha) }\end{array}$ & $\begin{array}{c}\text { Core Wet 70\% } \\
\text { AKDE (ha) }\end{array}$ & $\begin{array}{c}\text { Core Dry 70\% } \\
\text { AKDE (ha) }\end{array}$ \\
\hline ARGL1 & $325,851(221,430-450,124)$ & $4587(3551-5773)$ & $\begin{array}{c}22,593 \\
(14,723-32,122)\end{array}$ & $1292(1000-1620)$ & $8415(5484-11,963)$ \\
ARGL3 & $118,970(79,393-166,441)$ & $2068(1729-2436)$ & $27,066(5484-11,963)$ & $506(423-597)$ & $12,551(6078-21,332)$ \\
\hline
\end{tabular}

During the nearly week-long tagging period at Barba Azul in 2019, observers (L.C.D., L.C., L.F.) twice spotted BTMs carrying transmitters, both in the immediate vicinity of where they were tagged, and also while birds were flying together in the evening over the "bajio" drinking areas. Transmitters appeared to be well-fitting, not limiting the birds' flying, and with antennae intact. Though individual recognition was impossible in these instances, these sightings, as well as the tracking data collected, indicated to us that the experience of being trapped and tagged probably did not seriously alter the birds' use of the areas around the tagging site, nor change their associations with conspecifics.

On 13 August 2021, a BTM was spotted and photographed (by park ranger Miguel Martinez-Diaz) still wearing a collar nearly two years after it was first deployed (Figure 4). 


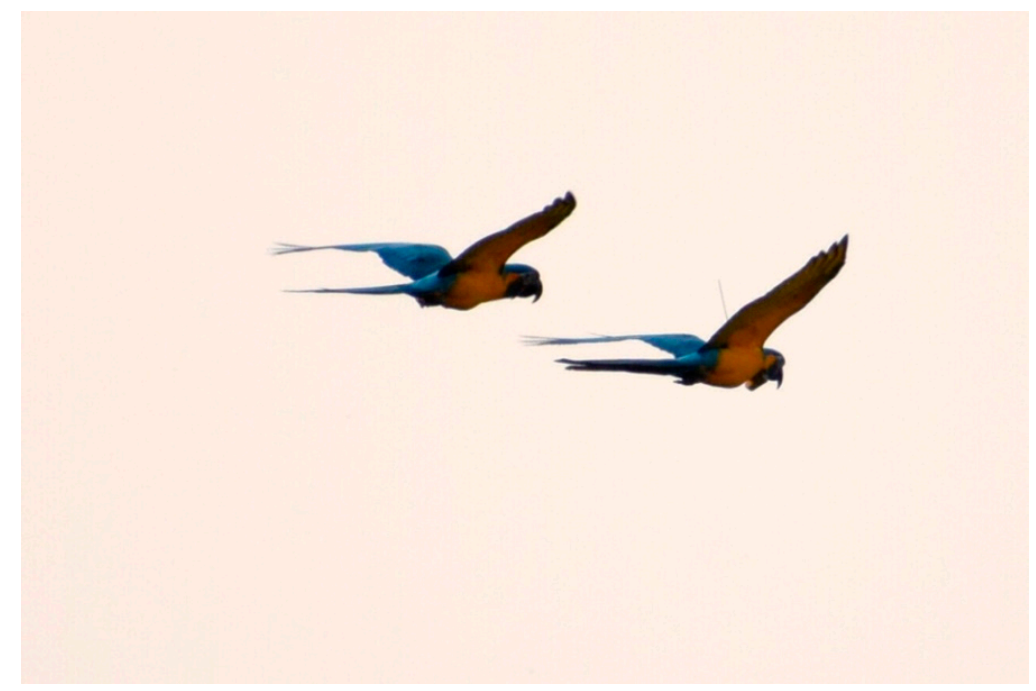

Figure 4. Pair of BTMs photographed in Barba Azul 13 August 2021, with one still carrying a Geotrak collar (right). Rted with permission by Miguel Martinez-Diaz.

\subsection{Migration, and Breeding Season Ranges and Movements}

Two of the tagged birds (ARGL1 and ARGL3) migrated away from Barba Azul on the same date (27 September 2019), but diverged in their paths by about $90^{\circ}$, and did not interact again during the life of their PTT's. On inspection, ARGL1 was considered to be migrating, i.e., not yet settled, for 24.5 days and ARGL3 for 13.4 days. Distances moved on migration were, on average, $7.5 \mathrm{~km} /$ day for ARGL1 and $4.9 \mathrm{~km} /$ day for ARGL3. Maximum distances measured between consecutive points ( 2 day spread) while on migration were $59 \mathrm{~km} /$ day for ARGL1 and $18 \mathrm{~km} /$ day for ARGL3. Accumulated daily distances moved to the end of transmissions are displayed in Figure 5.

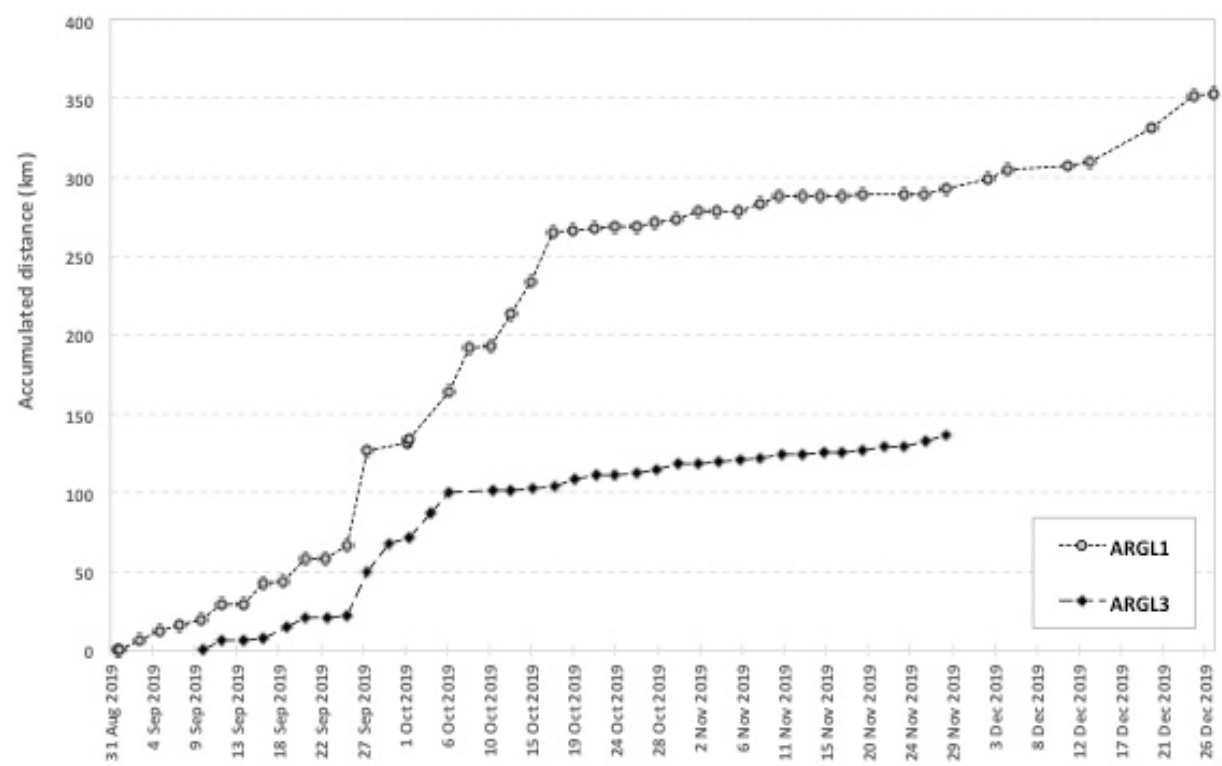

Figure 5. Accumulated daily distances traveled by two migrant BTMs tagged at Barba Azul.

The two migrant birds eventually settled in distinct areas that were both $\sim 50-100 \mathrm{~km}$ from Barba Azul, still within the Llanos de Moxos region, and still within the boundaries of the northwestern subpopulation's distribution. ARGL3 used the same general region through to the end of transmissions. ARGL1, however, used two different spots in the same period, these being approximately $30 \mathrm{~km}$ apart. While at wet season locations, average daily movements (away from few regular nighttime roosts) were smaller than while at Barba 
Azul, at $3.7 \mathrm{~km}$ average for ARGL1 and $1.2 \mathrm{~km}$ for ARGL3. Similarly, wet season range sizes were smaller than during the dry season. ARGL1 used a 95\% AKDE of 4587 ha and a core $70 \%$ AKDE of 1292 ha. ARGL3 used a 95\% AKDE of 2068 ha and a core 70\% AKDE area of 506 ha (Table 1 and Supplemental Figure S2).

\subsection{Wet Season Ground-Truthing Surveys}

Results, observations, and information on community outreach obtained during the nest surveys undertaken by Armonía are continually reported in regular Armonía newsletters and elsewhere $[22,27,48]$. Despite gaining access to both final locations where we tracked ARGL1 and ARGL3, we found no birds still wearing tags there. Habitat at the two sites both had a greater availability of Mauritia flexuosa palms, which are not present at Barba Azul. The team did succeed in finding 15 BTM nests across three breeding areas, and observed between 93 and 104 BTMs in a survey area of approximately 30,700 ha. In a previously discovered roosting site, we counted 56 BTMs roosting in a small Motacúdominated forest island. Based on the location data of the 15 known nests, the average distance from a nest to the second nearest known nest is $4.48 \mathrm{~km}$. The total distance between the southernmost nest and the northernmost nest is $63.25 \mathrm{~km}$. Motacú forests are found on average at a distance of $1.35 \mathrm{~km}$ from a nest [27].

\section{Discussion}

Prior to this study, nesting sites of the vitally important sub-population of Bluethroated macaws from Barba Azul were unknown. In general, tracking birds to their breeding areas is a far less common practice than tracking from their breeding sites, in part because it offers fewer opportunities to trap in sites that are visited regularly. For this reason, and also because the species is Critically Endangered and the smallest macaw species tracked to date, the work required multiple phases of testing to implement tracking with wild birds in the safest means possible. Ultimately, the methods used allowed us to capture and track two wild BTMs to two breeding areas where nests were later found. The migration data also inspired the initiation of conversations with the relevant landowners about best practices in ranching for macaw conservation [37,48]. We believe that follow-up efforts can now be more focused and effective, and lead to improved chances of our ultimate goal of better protecting the birds of Barba Azul throughout the year, monitoring their reproductive success, and improving the chances for the species' long-term conservation at Barba Azul and more widely in the northern Llanos de Moxos.

\subsection{Tracking Results}

The two tagged birds that continued to transmit through migration (ARGL1 and ARGL3) demonstrated the durability and effectiveness of the Geotrak units for tracking wild Blue-throated Macaws for many months. The 2021 rediscovery of a wild bird still carrying a now-defunct Geotrak collar also demonstrates that both long and short-term deployments should be feasible with the species. Although the date of outbound migration (27 September) was earlier than expected from previous Barba Azul census data [22,50], it was identical for our two migrant birds. Prior to migrating, birds only occasionally left the immediate area protected by Barba Azul, confirming the critical location and size of the reserve. However, our data are based on a small window of time of only a few weeks, thus it is likely that a longer tracking period of these and other birds within Barba Azul would reveal a wider area of use. Similarly, it is highly likely that a longer tracking period for ARGL1 and ARGL2 could have revealed more distant areas of use beyond the reserve. Yet, relative to the size of protected areas in the region, overall range sizes of $95 \%$ AKDE using all locations (from both dry and wet season data and while on migration) were quite large (at 325,851 ha for ARGL1 and 118,970ha for ARGL3 (Table 1)). Still, our home range estimates should clearly be considered minimum estimates for both seasons, and conservation needs assessed with this caveat. A future effort focused on tracking birds for a complete season of residence inside Barba Azul is a priority for future work. 
Both birds tracked on migration eventually settled into two distinct areas $\sim 50-100 \mathrm{~km}$ from Barba Azul, although after leaving in divergent directions. This result, combined with the subsequent nest discoveries, suggests that BTM breeding sites are probably widely scattered across the Llanos de Moxos landscape. Their scattered distribution could make conservation efforts more difficult, but is important for understanding the ecoregion-level needs for saving the species from extinction. The choice to program for frequent location fixes proved very useful to learn the specific timing, direction, and length of migration periods; moreover, it helped indicate specific areas of the Beni where the birds visited prior to settling down. Future work may require longer, less detailed programming.

These data have and will continue to guide additional overflights and ground-truthing searches for other nesting sites in nearby locations. Adding a banding program of young at nest sites discovered here could also help definitively link reproductive outputs to new recruits at Barba Azul.

\subsection{Distances Traveled}

The distance an individual macaw can travel has different implications. Besides indicating a birds' physical capacity to cover a given distance, it is also important from a conservation viewpoint. Can a given reserve protect the whole annual cycle for large and critically threatened birds such as Blue-throated Macaws? Does distance traveled tell us anything about the likelihood that Beni's different subpopulations of BTMs are really isolated? The measurements of wild individual macaw movements range are scanty, but comparison between what we learned in this study and a few other known examples are useful.

We found that the BTMs' daily locations averaged about 1 to $8 \mathrm{~km}$ apart across all seasons, with the largest distances recorded during migration periods where birds moved up to $59 \mathrm{~km}$ between days. The magnitude of these movements is hard to compare with other species as previous studies have used observations or calculated movements as distances among multiple points per day. For example, the last wild Spix's Macaw, Cyanopsitta spixi, reportedly moved up to $60 \mathrm{~km}$ from its night roost to its feeding place and back during the dry season [51]. Tracked Red-fronted Macaws (Ara rubrogenys) in Bolivia moved at least 9 to $28 \mathrm{~km}$ per day, and Blue-and-yellow Macaws (Ara ararauna) and Scarlet Macaws (Ara macao) in southeastern Peru moved on average at least 6 to $13 \mathrm{~km}$ per day $[30,52]$. In addition, one individual $A$. ararauna moved back and forth through the same $160 \mathrm{~km}$ path in one week, totaling a 320-km displacement [41].

The BTMs studied here migrated distances of approximately 50 to $100 \mathrm{~km}$ from their wintering ranges to their presumed breeding areas (Figure 5). These movements are similar to the majority of seasonal migrations documented in macaws to date. Blueand-yellow Macaws and Scarlet Macaws moved an average of 80 to $112 \mathrm{~km}$ from their nests post breeding in southeastern Peru and adjacent areas of Bolivia [30] A single Redfronted Macaw in Bolivia moved through areas up to $77 \mathrm{~km}$ from its wintering range before returning to the wintering range the next season [52]. In the Brazilian Pantanal, an ecosystem similar to the Llanos del Moxos, UHF studies documented seasonal movements of Hyacinth Macaws (Anodorhynchus hyacinthinus) of 36 to $50 \mathrm{~km}$ [29,53,54]. Migratory Great Green Macaws (Ara ambiguous) in Costa Rica have been found 35-40 km from their nests during the non-breeding season [55].

Similarly, comparisons of 95\% AKDE home range estimates are considerably smaller for BTMs both in the dry and in the wet season compared to home range estimates from southeastern Peru [30]. This means that whereas $A$. macao in Tambopata averaged home ranges of 11,900 ha in the breeding season and $A$. ararauna 16,700 [30], our two BTMs ranged only over approximately 4500 and 2000 ha as estimated from their wet season data using the AKDE procedure (Supplemental Table S2). In the non-breeding season, the differences were even more notable, with our 2 tagged BTMs ranging over 23,000 and 27,000 ha respectively, and A. macao averaging 206,500 and A. ararauna 191,000 [30]. 
Differences in distances moved may be due to body size and physiology, but may also reflect the density and seasonality of food available in Barba Azul and the Llanos de Moxos compared to other sites. Spix's macaws inhabit a semi-arid region where food abundances should fluctuate widely and they may need to move long distances to dispersed food patches. In Barba Azul, some Motacú patches are nearly monodominant, possibly due to past human influences, and can produce fruit nearly all year [25,35], so that the birds there do need not to move far for feeding. In contrast, in Tambopata, Peru, food abundance shows large seasonal fluctuations [56] and feeding trees are often scattered in a more diverse forest matrix. The flight range of BTMs that left Barba Azul suggests that the species is able to fly similar distances as other macaws. However, at least for BTMs using Barba Azul, there seems to be scant evidence from observations, or from our study, for partial migration, use of intermediate stopover sites, or more nomadic behavior. The energetic reserves needed for their longest movements, even while present in high densities, were obtained while in Barba Azul, reinforcing the seasonal importance of the reserve for this BTM population.

\subsection{Challenges Working with the Psittacidae}

Although tracking BTMs required multiple field seasons of testing equipment and capture methods, ultimately, we did manage to determine methods that allowed us to capture and track three wild BTMs, including to two likely breeding sites. The work shows the potential to use satellite telemetry for biological and conservation questions with this species and within the Psittacidae. While not all our methods or results are reported here, out of an abundance of conservation concern, we hope that sharing our experiences with testing, using satellite telemetry units on macaws, and analyzing habitat features can help other researchers faced with similar challenges, and especially those with conservation questions best answered through the use of satellite telemetry.

Despite our success, several practical and logistical features of studying any parrot species makes the use of satellite telemetry on this family a complicated task. One of the greatest difficulties is the fact that the ideal (and necessarily robust) transmitter design appears to be quite species-specific. Although with some other parrot species, researchers have had good results with backpack models or hardened plastic materials set as collars, our birds destroyed all such models in minutes, piercing antennae and casings through any seams or corners they could find. The successful units, parrot collars by Geotrack, are made by hand by the company's founder, using hard-won skills known best to himself [57] making them quite unique (and also expensive), and therefore hard to deploy on a larger scale. Manufacturers are understandably loathe to invest much time researching and improving any "weakness" in a transmitter model to be used on parrots when a model will see very limited use in small studies. This reality gives researchers limited, mostly expensive options. Moreover, we found that many institutions with captive parrots were unwilling to allow testing with their captive animals; we had to find an institution outside the Americas with which to collaborate on the critical step of first testing out dummy transmitter designs. We also still lack a truly comprehensive understanding of the potential effects of attaching units to parrots in different configurations, as nearly all studies on either captive or wild animals, including our own, involve extremely small sample sizes. Ideally, we would also quickly remove any defunct unit from a wild bird, but we are still seeking a means to do so without a large re-trapping effort. We would welcome suggestions for reliable drop-off mechanisms that could be added to collar designs without adding excessive weight. Overall, our experience with this species has taught us that, despite the great advances in the technology of satellite telemetry in recent years, and with the many projects still needing to be done to study parrots of great conservation concern, the Psittacidae family is still relatively understudied and requiring considerably more innovation for their efficient and effective study. Therefore, as a final recommendation for the future, we urge fellow researchers and tinkerers to consider expending more effort with this particularly underserved group of birds. 
Supplementary Materials: The following are available online at https: / www.mdpi.com/article/ 10.3390/d13110564/s1, Figure S1: Map of Barba Azul Nature Reserve, with tracks of 3 BTM;s and 95\% Home Range Estimates for 2 BTM's (ARGL1 and ARGL3) with sufficient data for home range analyses., Figure S2: Map of 95\% Home Range Estimates for 2 BTMs (ARGL1_Hernan on left and ARGL3_Tjalle on right) on wet season (breeding season) sites. Table S1: Argos Id's and morphometric measures of captured wild Blue-throated Macaws from Barba Azul., Video S1: Video of captive BTM tagged with an MTI dummy transmitter at Loro Parque, Tenerife, Spain. Video S2: Video of release of a wild BTM with a Geotrak transmitter. Video S3: Animation of 3 BTM movements around Barba Azul, using the R program "MoveVis".

Author Contributions: Conceptualization, L.C.D., T.B., L.C., P.d.T.Z.A., D.J.B., S.K.H., R.W.S.-A., and A.B.H.; methodology, L.C.D., T.B., L.C., P.d.T.Z.A., L.F., and D.J.B.; formal analysis, L.C.D. and L.C.; investigation, L.C.D., T.B., L.C., P.d.T.Z.A., and L.F.; data curation, L.C.D., L.C., and L.F.; writingoriginal draft preparation, L.C.D., T.B., L.C., P.d.T.Z.A., and D.J.B.; writing-review and editing, L.C.D., T.B., L.C., P.d.T.Z.A., D.J.B., S.K.H., R.W.S.-A., and A.B.H.; project administration, T.B., S.K.H., R.W.S.-A., and A.B.H. All authors have read and agreed to the published version of the manuscript.

Funding: This research was funded by the Mohammed bin Zayed Foundation, project number 180517998, the American Bird Conservancy, and anonymous private donors.

Institutional Review Board Statement: The study was conducted according to the guidelines of the Declaration of Helsinki, and approved by the Animal Care and Use Committee of the University of Florida, Gainesville (protocol \#201709973). It was also approved by the Ministerio de Medio Ambiente y Agua (Bolivia): MMAYA/VMABCCGDF/DGAP/MEG No 0228/2017.

Data Availability Statement: Public data is redacted after migration due to poaching pressure and concern for private landowners. Requests for data sharing can be directed to Asociación Armonía as noted in the text.

Acknowledgments: The authors wish to thank Loro Parque Foundation (esp. David Waugh and Marcia Weinzetll) for assisting us with testing units on their captive Blue-throated macaws. In addition, we thank Keith Le Sage of Geotrak, Sarah Davidson of Movebank, and Torbjorn Haugaasen of the Norwegian University of Life Sciences for advice and aid to the project. For field assistance, we thank Carlos, Yuri, Hernan, and John Terborgh. Luciano Naka helped in reading and editing an early draft of the manuscript. We also want to thank the Museum of Natural History Alcide d'Orbigny for helping us to obtain government permit to conduct this research.

Conflicts of Interest: The authors declare no conflict of interest. The funders had no role in the design of the study; in the collection, analyses, or interpretation of data; in the writing of the manuscript, or in the decision to publish the results.

\section{References}

1. Bridge, E.S.; Thorup, K.; Bowlin, M.S.; Chilson, P.B.; Diehl, R.H.; Fléron, R.W.; Hartl, P.; Kays, R.; Kelly, J.F.; Robinson, W.D.; et al. Technology on the move: Recent and forthcoming innovations for tracking migratory birds. BioScience 2011, 61, 689-698. [CrossRef]

2. Crossin, G.T.; Cooke, S.J.; Goldbogen, J.A.; Phillips, R.A. Tracking fitness in marine vertebrates: Current knowledge and opportunities for future research. Mar. Ecol. Prog. Ser. 2014, 496, 1-17. [CrossRef]

3. Guilford, T.; Åkesson, S.; Gagliardo, A.; Holland, R.A.; Mouritsen, H.; Muheim, R.; Wiltschko, R.; Wiltschko, W.; Bingman, V.P. Migratory navigation in birds: New opportunities in an era of fast-developing tracking technology. J. Exp. Biol. 2011, 214, 3705-3712. [CrossRef]

4. Robinson, W.D.; Bowlin, M.S.; Bisson, I.; Shamoun-Baranes, J.; Thorup, K.; Diehl, R.H.; Kunz, T.H.; Mabey, S.; Winkler, D.W. Integrating concepts and technologies to advance the study of bird migration. Front. Ecol. Environ. 2010, 8, 354-361. [CrossRef]

5. Wikelski, M.; Kays, R.W.; Kasdin, N.J.; Thorup, K.; Smith, J.A.; Swenson, G.W., Jr. Going wild: What a global small-animal tracking system could do for experimental biologists. J. Exp. Biol. 2007, 210, 181-186. [CrossRef] [PubMed]

6. Skewgar, E.; Boersma, P.D.; Simeone, A. Winter migration of Magellanic Penguins (Spheniscus magellanicus) along the southeastern Pacific. Waterbirds 2014, 37, 203-209. [CrossRef]

7. Martell, M.S.; Henny, C.J.; Nye, P.E.; Solensky, M.J. Fall migration routes, timing, and wintering sites of North American ospreys as determined by satellite telemetry. Condor 2001, 103, 715-724. [CrossRef]

8. McIntyre, C.L. Quantifying Sources of Mortality and Wintering Ranges of Golden Eagles from Interior Alaska Using Banding and Satellite Tracking. J. Raptor Res. 2012, 46, 129-134. [CrossRef] 
9. Davenport, L.C.; Goodenough, K.; Haugaasen, T. Birds of two oceans? Trans-Andean and divergent migration of Black Skimmers (Rynchops niger) from the Peruvian Amazon. PLoS ONE 2016, 11, e0144994. [CrossRef] [PubMed]

10. Cappelle, J.; Iverson, S.A.; Takekawa, J.Y.; Newman, S.H.; Dodman, T.; Gaidet, N. Implementing telemetry on new species in remote areas: Recommendations from a large-scale satellite tracking study of African waterfowl. Ostrich 2011, 82, 17-26. [CrossRef]

11. Hill, J.M.; Sandercock, B.K.; Renfrew, R.B. Migration Patterns of Upland Sandpipers in the Western Hemisphere. Front. Ecol. Evol. 2019, 7, 426. [CrossRef]

12. Pedler, R.D.; Ribot, R.F.H.; Bennett, A.T.D. Extreme nomadism in desert waterbirds: Flights of the banded stilt. Biol. Lett. 2014, 10, 20140547. [CrossRef]

13. Lutcavage, M.E.; Brill, R.W.; Skomal, G.B.; Chase, B.C.; Howey, P.W. Results of pop-up satellite tagging of spawning size class fish in the Gulf of Maine: Do North Atlantic Bluefin tuna spawn in the mid-Atlantic? Can. J. Fish. Aquat. Sci. 1999, 56, 173-177. [CrossRef]

14. Pilcher, N.E.; Rodriguez-Zarate, C.J.; Antonopoulou, M.A.; Mateos-Molina, D.; Sekhar-Das, H.; Abdullah-Bugla, I. Combining laparoscopy and satellite tracking: Successful round-trip tracking of female green turtles from feeding areas to nesting grounds and back. Glob. Ecol. Cons. 2020, 23, e01169. [CrossRef]

15. Takekawa, J.Y.; Newman, S.H.; Xiao, X.; Prosser, D.J.; Spragens, K.A.; Palm, E.C.; Yan, B.; Li, T.; Lei, F.; Zhao, D.; et al. Migration of waterfowl in the East Asian flyway and spatial relationship to HPAI H5N1 outbreaks. Avian Dis. 2010, 54 (Suppl. 1), $466-476$. [CrossRef] [PubMed]

16. Chan, Y.C.; Tibbitts, T.L.; Lok, T.; Hassell, C.J.; Peng, H.B.; Ma, Z.; Zhang, Z.; Piersma, T. Filling knowledge gaps in a threatened shorebird flyway through satellite tracking. J. Appl. Ecol. 2019, 56, 2305-2315. [CrossRef]

17. Sick, H.; Teixeira, D.M.; Gonzaga, L.P. A nossa descoberta da pátria da arara Anodorhynchus leari. Anais da Acadamia Bras Ciências 1979, 51, 575-576.

18. Styles, F.G.; Skutch, A.F. A Guide to the Birds of Costa Rica; Comstock Publishing Associates: Ithaca, NY, USA, 1989.

19. Forshaw, J.M. Parrots of the World, 3rd ed.; Landsdowne Editions: Melbourne, Australia, 1989.

20. Jordan, O.C.; Munn, C.A. First observations of the Blue-throated Macaw in Bolivia. Wilson Bull. Wilson Ornithol. Soc. 1993, 105, 694-695.

21. Ortiz-von Halle, B. Bird's-Eye View: Lessons from 50 Years of Bird Trade Regulation E Conservation in Amazon Countries; TRAFFIC: Cambridge, UK, 2018.

22. Herzog, S.K.; Maillard, O.Z.; Boorsma, T.; Sanchez-Avila, G.; Garcia-Soliz, V.H.; Paca-Condori, A.; Vailez de Abajo, M.; Soria-Auza, W. First systematic sampling approach to estimate the global population size of the Critically Endangered Blue-throated Macaw (Ara glaucogularis). Bird Conserv. Int. 2021, 31, 293-311. [CrossRef]

23. Hordijk, I.; Meijer, F.; Nissen, E.; Boorsma, T.; Poorter, L. Cattle affect regeneration of the palm species Attalea princeps in a Bolivian forest-savannah mosaic. Biotropica 2019, 51, 28-38. [CrossRef]

24. Lombardo, U.; Veit, H. The origin of oriented lakes: Evidence from the Bolivian Amazon. Geomorphology 2014, 204, 502-509. [CrossRef]

25. Lombardo, U.; Iriarte, J.; Hilbert, L.; Ruiz-Pérez, J.; Capriles, J.M.; Veit, H. Early Holocene crop cultivation and landscape modification in Amazonia. Nature 2020, 581, 190-193. [CrossRef]

26. Berkunsky, I.; Daniele, G.; Kacoliris, F.P.; Díaz-Luque, J.A.; Silva Frias, C.P.; Aramburu, R.M.; Gilardi, J.D. Reproductive parameters in the critically endangered Blue-throated Macaw: Limits to the recovery of a parrot under intensive management. PLoS ONE 2014, 9, e99941. [CrossRef] [PubMed]

27. Boorsma, T.; Asociación Armonia, Santa Cruz, Bolivia. 2020; Unpublished data.

28. Kennedy, E.M.; Kemp, J.R.; Mosen, C.C.; Perry, G.L.W.; Dennis, T.E. GPS telemetry for parrots: A case study with the Kea (Nestor notabilis). Auk Ornithol. Adv. 2015, 132, 389-396. [CrossRef]

29. Antas, P.T.Z.; Carrara, L.A.; Yabe, R.S.; Ubaid, F.K.; Oliveira-Junior., S.B.; Vasques, E.R.; Ferreira, L.P. A Arara-Azul na Reserva Particular do Patrimônio Natural SESC Pantanal; The Hyacinth Macaw in the SESC Pantanal Natural Heritage Private Reserve; Conhecendo o Pantanal 6; SESC Serviço Social do Comércio, Departamento Nacional: Rio de Janeiro, Brazil, 2010; Available online: http:/ / www.sescpantanal.com.br/arquivos / cadastro-itens/layout-6/arquivos/file-635877033528123910.pdf (accessed on 4 November 2021). (In Portuguese)

30. Brightsmith, D.J.; Boyd, J.; Hobson, E.A.; Randal, C.J. Satellite telemetry reveals complex migratory movement patterns of two large macaw species in the western Amazon basin. Avian Conserv. Ecol. 2021, 16, 14. [CrossRef]

31. Rycken, S.; Warren, K.S.; Yeap, L.; Jackson, B.; Riley, K.; Page, M.; Dawson, R.; Smith, K.; Mawson, P.R.; Shephard, J.M. Assessing Integration of Black Cockatoos Using Behavioral Change Point Analysis. J. Wildl. Manag. 2019, 83, 334-342. [CrossRef]

32. Davenport, L.C.; Boorsma, T.; Carrara, L.A.; Antas, P.; Faria, L.; Brightsmith, D.J.; Herzog, S.K.; Soria-Auza, R.W.; Hennessey, A.B. Data from: Satellite telemetry of Blue-throated macaws in Barba Azul Nature Reserve (Beni, Bolivia) reveals likely breeding areas. Movebank Data Repos. 2021. [CrossRef]

33. Haase, R.; Beck, G. Structure and composition of savanna vegetation in northern Bolivia: A preliminary report. Brittonia 1989, 41, 80-100. [CrossRef]

34. Wittmann, F.; Householder, E.; de Oliveira, A.; Lopes, A.; Junk, W.J.; Piedade, M.T. Implementation of the Ramsar Convention on South American wetlands: An update. Res. Rep. Biodivers. Stud. 2015, 4, 47-58. [CrossRef] 
35. Capriles, J.M.; Lombardo, U.; Maley, B.; Zuna, C.; Veit, H.; Kennett, D.J. Persistent Early to Middle Holocene tropical foraging in southwestern Amazonia. Sci. Adv. 2019, 5, eaav5449. [CrossRef]

36. Mayle, F.E.; Langstroth, R.P.; Fisher, R.A.; Meir, P. Long-term forest-savannah dynamics in the Bolivian Amazon: Implications for conservation. Philos. Trans. R. Soc. B Biol. Sci. 2007, 362, 291-307. [CrossRef] [PubMed]

37. Callaú, L.N.M.; Boorsma, T. Guía Práctica Para Ganadería de Armonización: La Ganadería Sostenible Para el Beni; Asociación Civil Armonía: Santa Cruz de la Sierra, Bolivia, 2019; Available online: http://armoniabolivia.org/wp-content/uploads/2020/01/ Gu\%C3\%ADa-Ganader\%C3\%ADa-Sostenible-baja.pdf (accessed on 8 August 2020).

38. Davenport, L.C.; Nole, I.; Carlos, N. East with the Night: Longitudinal migration of the Orinoco Goose (Neochen jubata) between Manú National Park, Peru and the Llanos de Moxos, Bolivia. PLoS ONE 2012, 7, e46886. [CrossRef]

39. Barron, D.G.; Brawn, J.D.; Weatherhead, P.J. Meta analysis of transmitter effects on avian behaviour and ecology. Methods Ecol. Evol. 2010, 1, 180-187. [CrossRef]

40. CLS (Collecte Localisation Satellites). Argos User's Manual; Collecte Localisation Satellites: Ramonville Saint-Agne, France, 2011; 69p, Available online: http:/ / www.argos-system.org/manual/ (accessed on 14 February 2021).

41. Boyd, J.D.; Brightsmith, D.J. Error properties of Argos satellite telemetry locations using Least Squares and Kalman Filtering. PLOS ONE 2013, 8, e63051. [CrossRef]

42. Douglas, D.C.; Weinzierl, R.C.; Davidson, S.; Kays, R.; Wikelski, M.; Bohrer, G. Moderating Argos location errors in animal tracking data. Methods Ecol. Evol. 2012, 3, 999-1007. [CrossRef]

43. Fleming, C.H.; Calabrese, J.M.; Mueller, T.; Olson, K.A.; Leimgruber, P.; Fagan, W.F. Non-Markovian maximum likelihood estimation of autocorrelated movement processes. Methods Ecol. Evol. 2014, 5, 462-472. [CrossRef]

44. Calabrese, J.M.; Fleming, C.H.; Gurarie, E. ctmm: An r package for analyzing animal relocation data as a continuous-time stochastic process. Methods Ecol. Evol. 2016, 7, 1124-1132. [CrossRef]

45. R Core Team. R: A Language and Environment for Statistical Computing; R Foundation for Statistical Computing: Vienna, Austria, 2020; Available online: https: / / www.R-project.org/ (accessed on 9 February 2021).

46. Uhlenbeck, G.E.; Ornstein, L.S. On the theory of the Brownian motion. Phys. Rev. 1930, 36, 823. [CrossRef]

47. Silva, I.; Fleming, C.H.; Noonan, M.J.; Alston, J.; Folta, C.; Fagan, W.F.; Calabrese, J.M. Autocorrelation-informed home range estimation: A review and practical guide. EcoEvoRxiv 2021. preprint. Available online: https://ecoevorxiv.org/23wq7/ (accessed on 9 February 2021).

48. Asociación Civil Armonía. Discoveries from 2020 Nest Search Expedition Guide Next Steps for Blue-Throated Macaw Research and Conservation 2020; Asociación Civil Armonía: Santa Cruz de la Sierra, Bolivia, 2020; Available online: http: / /armoniabolivia.org/ 2020/04/28/discoveries-guide-next-steps-for-research-and-conservation (accessed on 9 February 2021).

49. Weinzetll, M.; (Loro Parque Foundation, Tenerife, Spain). Personal communication, 2018.

50. Asociación Civil Armonía. Barba Azul Nature Reserve; May 2020 Update Report; Asociación Civil Armonía: Santa Cruz de la Sierra, Bolivia, 2020; Available online: http:/ / armoniabolivia.org/wp-content/uploads/2020/09/Barba-Azul-Nature-ReserveMay-2020-Update-Report.pdf (accessed on 9 February 2021).

51. Da-Ré, M.A.; (Centro de Economia Verde, Fundação Certi Florionopolis, Florianópolis, Brazil). Personal communication, 2020.

52. Meyer, C. Spatial Ecology and Conservation of the Endemic and Endangered Red-Fronted MACAW (Ara Rubrogenys) in the Bolivian Andes. Diploma Thesis, Georg-August University Göttingen, Göttingen, Germany, 2010. Available online: http: / / armoniabolivia.org/wp-content/uploads/2016/07/01_2010-Meyer-DiplomArbeit-GoettingenUniversity.pdf (accessed on 9 February 2021).

53. Guedes, N.M.R.; Seixas, G.H.F. Métodos para estudos de reprodução de Psitacídeos. In Ecologia e Conservação de Psitacídeos no Brasil; Melopsittacus Publicações Científicas: Belo Horizonte, Brasil, 2020; pp. 123-140.

54. Antas, P.; Fundação Pró-Natureza (Funatura), Brasilia, Brazil. 2020; Unpublished data.

55. Powell, G.; Wright, P.; Aleman, U.; Guindon, C.; Palminteri, S.; Bjork, R. Research Findings and Conservation Recommendations for the Great Green Macaw (Ara Ambigua) in Costa Rica; Centro Cientifico Tropica: San Jose, Costa Rica, 1999.

56. Brightsmith, D.J.; Hobson, E.A.; Martinez, G. Food availability and breeding season as predictors of geophagy in Amazonian parrots. IBIS 2018, 160, 112-129. [CrossRef]

57. Le Sage, K.; (Geotrak, Raleigh, NC, USA). Personal communication, 2018. 